\title{
Synthesis of all four stereoisomers of 5-hydroxy-4-methyl-3-heptanone using plants and oyster mushrooms
}

\author{
Björn Bohman ${ }^{\text {a }}$, C. Rikard Unelius ${ }^{\text {a, b,* }}$

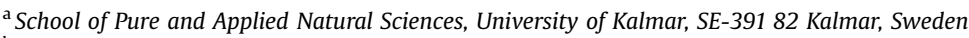 \\ ${ }^{\mathrm{b}}$ The New Zealand Institute for Plant E' Food Research Limited, Canterbury Research Centre, Lincoln, 7608, New Zealand
}

\section{A R T I C L E I N F O}

Article history:

Received 25 March 2009

Received in revised form 5 August 2009

Accepted 20 August 2009

Available online 25 August 2009

\section{Keywords:}

Sitophilure

Plants

Mushrooms

Enantioselective, $\beta$-Hydroxyketone

\section{A B S T R A C T}

All four possible stereoisomers of 5-hydroxy-4-methyl-3-heptanone were synthesized from common achiral reagents using fast, straightforward organic synthesis, including the use of whole tissue of Daucus carota, Solanum melongena, and Pleurotus ostreatus.

(c) 2009 Elsevier Ltd. All rights reserved.

\section{Introduction}

(4R,5S)-5-Hydroxy-4-methyl-3-heptanone ((4R,5S)-1a), known as Sitophilure (Fig. 1), has been found to be an aggregation pheromone for Sitophilus weevils, such as the rice weevil Sitophilus oryzae and the maize weevil Sitophilus zeamais. ${ }^{1}$ One of the anti isomers of this compound, $(4 S, 5 S)-2 a$, was found to be a compound specific to males, when volatile emissions from individuals of the lucerne weevil Sitona discoideus were analyzed, in order to attempt the identification of its sex pheromone. ${ }^{2}$ To be able to determine whether $(4 S, 5 S)-2 a$ was in fact a pheromone for this species, the compound

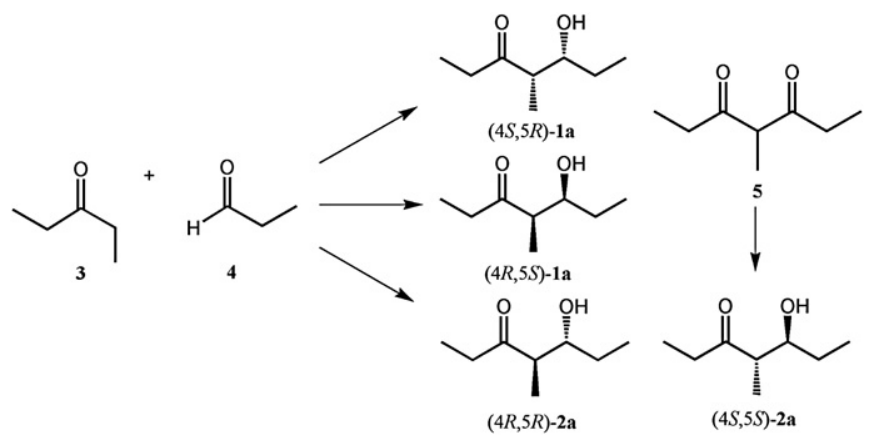

Figure 1. Starting materials and target compounds.

\footnotetext{
* Corresponding author. Tel.: +46 708101514; fax: +46 480446262

E-mail address: rikard.unelius@hik.se (C.R. Unelius).
}

had to be synthesized. We also wanted to obtain the remaining three stereoisomers for tests of synergetic or inhibitory effects.

Numerous routes to the various stereoisomers of 5-hydroxy-4methyl-3-heptanone (1a and $\mathbf{2 a}$ ) have been reported over the last decades. ${ }^{3}$ For example Mori and Ebata have prepared all possible isomers from methyl $(R)$-3-hydroxypentanoate ${ }^{3 \mathrm{~g}}$ and more recently new biocatalytic routes have been presented, among some are: Pilli's and Riatto's preparation of $(+)$-Sitophilure from methyl3-oxopentanoate using $S$. cerevisiae ${ }^{3 \mathrm{~b}}$ and the preparation of the same compound by Kalaitzakis et al. utilizing isolated NADPH-dependent ketoreductases. ${ }^{3 f}$ Our approach is based on the well known fact that diastereoselectivity of aldol additions of aldehydes to ketones can be directed by the choice of base in combination with added Lewis acids. We wanted to obtain the stereochemically pure isomers of 1a and 2a by utilizing diastereoselective aldol additions in combination with purifications by a common, commercially available lipase, whole tissue of vegetables and mushrooms, and column chromatography. By combining these methods, inexpensive and commercially available achiral reagents could be used to prepare substances highly enantioselectively with relative ease. Our aim of this project was to obtain the two syn isomers: $(4 R, 5 S)-\mathbf{1 a}$ and $(4 S, 5 R)-\mathbf{1 a}$ as well as the two anti isomers: $(4 R, 5 R)-$ $\mathbf{2 a}$ and $(4 S, 5 S)-\mathbf{2 a}$ as four separate samples in an isomeric purity greater than $95 \%$.

\section{Results and discussion}

In order to evaluate the relationship between stereochemistry and bioactivity, a synthesis of all four possible stereoisomers of 
5-hydroxy-4-methyl-3-heptanone ((4R,5S)-1a, $(4 S, 5 R)-\mathbf{1 a},(4 R, 5 R)-$ $\mathbf{2 a}$, and (4S,5S)-2a) was carried out. These syntheses consisted of 11 steps (Figs. 1 and 2) and total yields of the individual isomers ranged from 6 to 23\%. The crude syn products $1 \mathbf{a}$ and anti products 2a of 5-hydroxy-4-methyl-3-heptanone were synthesized by the aldol addition between 3-pentanone (3) and $n$-propanal (4). Transesterification using lipase Amano PS-D from Pseudomonas cepacia gave further enrichment of one pair of enantiomers and column chromatography on silica gel gave partial separation of the two pairs of diastereomers. Finally, the choice of plant tissue in the stereoselective hydrolysis of the acetate esters $\mathbf{1} \mathbf{b}$ and $\mathbf{2} \mathbf{b}$ formed by the lipase further enhanced the isomeric purity of the final products.

Compounds $(4 R, 5 S)-\mathbf{1 a}$ and $(4 S, 5 R)-\mathbf{1 a}$, the two syn isomers, were derived from $\mathbf{3}$ and $\mathbf{4}$, where the selectivity for the syn products was achieved by formation of a titanium enolate from $\mathrm{TiCl}_{4}$ and diisopropylethylamine. ${ }^{4}$ Further enhancement of the isomeric purity was achieved by a lipase-mediated transacetylation with Amano PS-D lipase and vinyl acetate. ${ }^{5}$ The main product $(4 S, 5 R)-\mathbf{1 b}$ was enriched further by column chromatography, ${ }^{6}$ taking advantage of the partial separation found for the two diastereomers on silica gel. The remaining alcohol was predominantly $(4 R, 5 S)-\mathbf{1 a}$, which was treated with lipase a second time, then acetylated and subjected to chromatography. The two acetate esters $(4 R, 5 S)-\mathbf{1 b}$ and (4S,5R)-1b were hydrolyzed selectively by the means of whole plant tissue of eggplant Solanum melongena, ${ }^{7}$ yielding $(4 R, 5 S)-\mathbf{1 a}$ and $(4 S, 5 R)-1 a$ in $>95 \%$ isomeric purity.

Compound $(4 R, 5 R)-2 \mathbf{a}$ was synthesized via a $\mathrm{Mg}(\mathrm{II})$-mediated aldol addition between $\mathbf{3}$ and 4, selectively forming the anti isomers. ${ }^{8}$ The initial aldol product, formed by an LDA reaction in THF, was treated with $\mathrm{MgBr}_{2}$-etherate at low temperature followed by warming to $\mathrm{rt}$, thus converting the syn product to a predominantly anti product. Analogously as for the syn products, a further increase in isomeric purity was achieved by a lipase-mediated

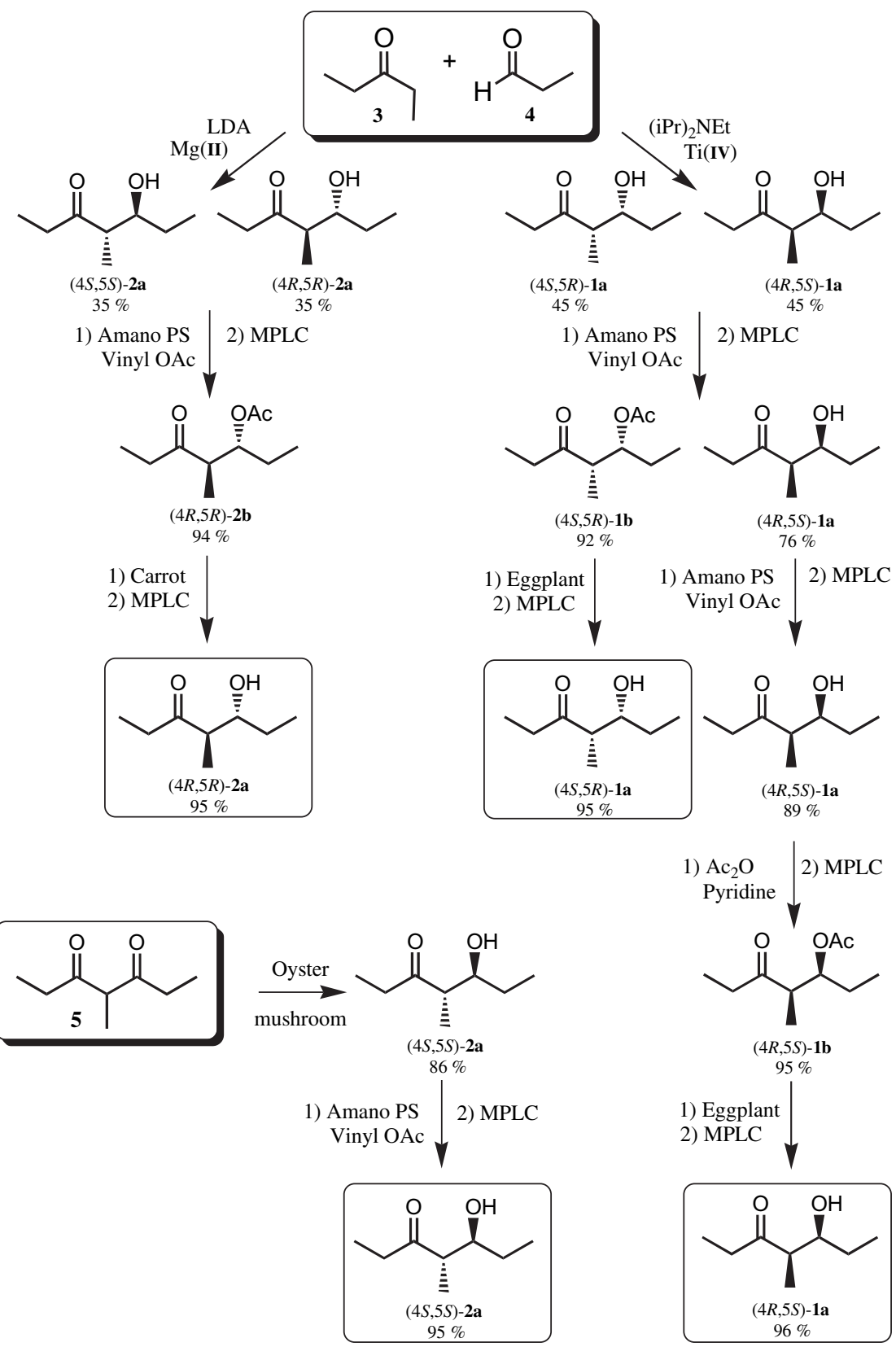

Figure 2. Synthesis of all four stereoisomers of 5-hydroxy-4-methyl-3-heptanone. 
transacetylation followed by chromatography of the acetate $(4 R, 5 R)-\mathbf{2 b}$. The selective hydrolysis of this ester was performed using whole tissue of carrot Daucus carota yielding the product $(4 R, 5 R)-2 \mathrm{a}$ in $95 \%$ isomeric purity.

Compound (4S,5S)-2a was synthesized by a regio- and enantioselective reduction of the diketone $\mathbf{5}$ by the means of whole tissue of oyster mushrooms Pleurotus ostreatus. The crude product was purified by chromatography and subjected to a lipase transacetylation. The enriched hydroxyketone was isolated from the formed acetate esters by chromatography yielding (4S,5S)-2a in $95 \%$ isomeric purity. In theory this stereoisomer could have been prepared by a similar method as for $(4 R, 5 S)$-1a, using rac-2a instead of rac-1a as starting material, but our method for preparation of $(4 S, 5 S)-\mathbf{2} \mathbf{a}$ is shorter.

It is important to note that the hydrolysis of the acetates $\mathbf{1 b}$ and $\mathbf{2 b}$ proceeded smoothly to the $\beta$-hydroxyketones $\mathbf{1 a}$ and $\mathbf{2 a}$ when the whole tissue of carrot and eggplant was used. This is in stark contrast to our attempts to execute chemical hydrolysis under alkaline standard conditions, which instantly yielded the elimination product 4-methyl-4-heptene-3-one. We also tried chemical hydrolysis under acidic conditions, as well as various commercial lipases (lipase B from Candida antarctica and Amano PS-D from Pseudomonas cepacia), esterase (Pig liver esterase), and protease (Subtilisin A) in attempts to hydrolyze and alcoholyze $\mathbf{1 b}$ and $\mathbf{2 b}$ without success.

The regio- and enantioselective reduction of the diketone $\mathbf{5}$ to $(4 S, 5 S)-2 \mathbf{a}$ by the use of oyster mushrooms (or other mushrooms) is an attractive alternative to the use of baker's yeast. Although excellent enantioselectivity and reasonable yields have been reported for reductions of $\beta$-diketones by baker's yeast, ${ }^{9}$ other authors report much lower yields (10-15\%) of the anti product (>96\% diastereomeric purity, no enantiomeric purity given) for the reduction using $\mathbf{5}$ as substrate. ${ }^{10}$ In our laboratory the yields and stereoselectivity of this reaction were substantially lower than those reported above, while in experiments using oyster mushrooms we have obtained a crude product containing $82 \%$ of the desired enantiomer in $95 \%$ chemical purity and $40 \%$ yield, without any use of commercial lipases (unpublished data).

\section{Conclusions}

We have described methods of stereoselective synthesis and separation, such as aldol addition, lipase transesterification, and column chromatography as well as ester hydrolysis mediated by plants and mushrooms. When these methods were employed individually they gave moderate isomeric purity of certain isomers of 5-hydroxy-4-methyl-3-heptanone 1a and 2a but when combined all stereoisomers of 1a and 2a could be prepared from common achiral starting materials in good enantiomeric and diastereomeric purity.

\section{Experimental}

\subsection{General}

For all synthesized compounds ${ }^{1} \mathrm{H}$ NMR and ${ }^{13} \mathrm{C}$ NMR spectra of $\mathrm{CDCl}_{3}$ solutions were recorded at $500 \mathrm{MHz}$ and $125 \mathrm{MHz}$, using a Varian Unity spectrometer. Chemical shifts were expressed in $\mathrm{ppm}$ in relation to tetramethylsilane, multiplicity ( $\mathrm{s}$, singlet; $\mathrm{d}$, doublet; $\mathrm{t}$, triplet; q, quintet and $\mathrm{m}$, multiplet), coupling constants $(\mathrm{Hz})$, and number of protons. The starting materials employed were obtained from commercial suppliers and used without further purification. All vegetables and mushrooms were obtained from the local supermarket. Mass spectra were obtained with an HP 6890GC interfaced to an HP 5973 mass selective detector, in electron impact mode ( $70 \mathrm{eV}$ ), with helium as the carrier gas. The GC was equipped with a BPX-70 column $(30 \mathrm{~m} \times 0.25 \mathrm{~mm}$, i.d. $\times 0.25 \mu \mathrm{m}$, SGE Australia). Enantioselective GC was performed with an HP 5890 GC fitted with a CYCLOSILB column $(30 \mathrm{~m} \times 0.25 \mathrm{~mm}$, i.d. $\times 0.25 \mu \mathrm{m}$, J \& W Scientific, USA). Column chromatography on silica gel (Merck 60, 0.040-0.063 mm) was carried out using a Separo medium pressure liquid chromatography (MPLC) system. ${ }^{6}$ The column inner diameter was 15,20 , or $25 \mathrm{~mm}$ and gradient elution was applied, using cyclohexane and increasing amounts of ethyl acetate. All chemicals used as starting materials in the syntheses, were used as delivered from Sigma-Aldrich (Sweden), and Alfa Aesar (Germany). Anhydrous solvents were used and reactions were carried out under nitrogen when appropriate.

\subsection{Synthesis of syn 5-hydroxy-4-methyl-3-heptanone (1a)}

In dichloromethane $(20 \mathrm{~mL})$, while stirring, 3-pentanone (3) $(0.43 \mathrm{~g}, 5.0 \mathrm{mmol})$ was dissolved and the solution was cooled to $-80^{\circ} \mathrm{C}$. Titanium tetrachloride $(0.60 \mathrm{~mL}, 5.5 \mathrm{mmol})$ was added dropwise. After $5 \mathrm{~min}$, diisopropylethylamine $(1.02 \mathrm{~mL}, 6.0 \mathrm{mmol})$ was added dropwise and the mixture was stirred for $1.5 \mathrm{~h}$ at the same temperature. Propanal (4) $(0.44 \mathrm{~mL}, 6.0 \mathrm{mmol})$ was added dropwise and stirring was continued for $1.5 \mathrm{~h}$ under the same conditions. $\mathrm{NH}_{4} \mathrm{Cl}$ (satd, aq, ca. $20 \mathrm{~mL}$ ) was added, the cooling bath was removed, and water (ca. $10 \mathrm{~mL}$ ) and diethyl ether (ca. $20 \mathrm{~mL}$ ) were added. The aqueous phase was separated and extracted with diethyl ether (ca. $2 \times 20 \mathrm{~mL}$ ), the combined organic phases were washed with brine (ca. $3 \times 20 \mathrm{~mL}$ ), dried over $\mathrm{MgSO}_{4}$, and the solvents were removed in vacuo, yielding the product $1 \mathbf{a}$ as a slightly yellow oil of $98 \%$ purity ( $0.62 \mathrm{~g}, 90 \%$ syn, $84 \%$ yield). GC-MS: 126(15), 97(14), 86(37), 70(18), 69(11), 59(16), 57(100), 55(15). For NMR see individual isomers.

\subsection{Synthesis of anti 5-hydroxy-4-methyl-3-heptanone (2a)}

Diisopropylamine $(12.6 \mathrm{~mL}, 90 \mathrm{mmol})$ was dissolved in THF $(200 \mathrm{~mL})$ and cooled to $0^{\circ} \mathrm{C}$. Butyllithium (2.0 M in pentane, $30.0 \mathrm{~mL}, 60 \mathrm{mmol}$ ) was added slowly while stirring and after $20 \mathrm{~min}$ at $\mathrm{rt}$, the mixture was cooled to $-70^{\circ} \mathrm{C}$. 3-Pentanone (3) $(5.16 \mathrm{~g}, 60 \mathrm{mmol})$ was added slowly and stirring was continued for $30 \mathrm{~min}$, whereafter propanal (4) (3.83 g, $66 \mathrm{mmol})$ was added. At the same temperature, after $20 \mathrm{~min}, \mathrm{MgBr}_{2} \cdot \mathrm{OEt}_{2}(19.4 \mathrm{~g}, 76 \mathrm{mmol})$ was added in one portion. After continued stirring for $5 \mathrm{~min}$, the mixture was allowed to reach rt and after another $3 \mathrm{~h} \mathrm{NH}_{4} \mathrm{Cl}$ (satd, aq, ca. $200 \mathrm{~mL}$ ) was added followed by diethyl ether (ca. $100 \mathrm{~mL}$ ) and water (ca. $50 \mathrm{~mL}$ ). The aqueous phase was extracted with diethyl ether (ca. $3 \times 50 \mathrm{~mL}$ ) and then the combined organic phases were washed with brine (ca. $2 \times 50 \mathrm{~mL}$ ) and dried over $\mathrm{MgSO}_{4}$. The solvents were removed in vacuo yielding the product $\mathbf{2 a}$ as a yellow oil of $54 \%$ purity ( $8.78 \mathrm{~g}, 71 \%$ anti). Yield: $55 \%$. After purification by MPLC 4.35 g product of $89 \%$ purity was collected, to be used for the next step. For GC-MS see 1a and for NMR see individual isomers.

\subsection{Synthesis of 4-methyl-3,5-heptanedione (5)}

To acetone (250 mL), 3,5-heptanedione (12.8 g, $0.098 \mathrm{~mol}$ ) and potassium carbonate (oven dried, $12.8 \mathrm{~g}, 0.094 \mathrm{~mol}$ ) were added at rt while stirring. After $15 \mathrm{~min}$, iodomethane ( $7.8 \mathrm{~mL}, 0.12 \mathrm{~mol})$ was added dropwise. The solution was heated to reflux overnight. After $16 \mathrm{~h}$, the heating was discontinued and at rt diethyl ether (ca. $200 \mathrm{~mL}$ ) was added and stirring was continued for $30 \mathrm{~min}$. Solids were filtered off and the remaining solution was concentrated in vacuo to yield 5 as a yellow oil of $90 \%$ purity (14.8 g), containing some residue of solvent. The product was used as such in the following steps. GC-MS ${ }^{11}$ and $\mathrm{NMR}^{3 \mathrm{f}}$ corresponded to literature data. GC-MS: 142(5), 114(5), 113(8), 86(45), 57(100). ${ }^{1} \mathrm{H}$ NMR $\delta: 3.68$ 
(q, $1 \mathrm{H}, J=7.1 \mathrm{~Hz}$ ), 2.49 (m, 4H), 1.31 (d, 3H, $J=7.1 \mathrm{~Hz}), 1.04$ (t, 6H, $J=7.2 \mathrm{~Hz}) ;{ }^{13} \mathrm{C}$ NMR $\delta$ : 207.9, 60.5, 35.0, 13.1, $7.8 \mathrm{ppm}$.

\subsection{Synthesis of $(4 R, 5 S)-5$-hydroxy-4-methyl-3-heptanone $((4 R, 5 S)-1 a)$}

Compound syn-1a [0.60 g, $4.2 \mathrm{mmol}$ (sum of isomers), 90\% syn] was mixed with vinyl acetate $(2.0 \mathrm{~g}, 23.2 \mathrm{mmol})$ and Amano PS-D lipase $(0.60 \mathrm{~g})$ was added. The mixture was incubated at $25^{\circ} \mathrm{C} /$ $120 \mathrm{rpm}$ in a shaking water bath. After 4 days the lipase was filtered off and rinsed with dichloromethane. The solvents were removed in vacuo and the enriched alcohol was isolated from the formed acetate by MPLC yielding a fraction of $331 \mathrm{mg}$ of 76\% enantiomeric purity. This product $(331 \mathrm{mg}, 2.3 \mathrm{mmol}$ ) was treated again with Amano PS-D lipase $(0.30 \mathrm{~g})$ in vinyl acetate $(1.0 \mathrm{~g}, 11.6 \mathrm{mmol})$ under the same conditions for 8 days. Analogous work-up and MPLC yielded $225 \mathrm{mg}$ (75\%) of (4R,5S)-1a of $89 \%$ isomeric purity.

The crude product $(4 R, 5 S)-\mathbf{1 a}(225 \mathrm{mg}, 1.6 \mathrm{mmol})$ was treated with acetic anhydride $(4.05 \mathrm{~g}, 40 \mathrm{mmol})$ in pyridine $(11.0 \mathrm{~g}$, $139 \mathrm{mmol}$ ) at rt overnight. Then the mixture was poured on ice and extracted with pentane (ca. $3 \times 15 \mathrm{~mL})$, washed with $\mathrm{CuSO}_{4}(10 \%, \mathrm{aq})$ until no change in color was observed (ca. $50 \mathrm{~mL}$ ), water (ca. $15 \mathrm{~mL}$ ) and brine (ca. $15 \mathrm{~mL}$ ), and dried over $\mathrm{MgSO}_{4}$. The solvents were removed in vacuo to yield a colorless product $(234 \mathrm{mg})$. This product was purified by repetitive MPLC (two times) to yield the ester (4R,5S)-1b in $95 \%$ isomeric purity (178 $\mathrm{mg}$, some solvent residue remaining).

The acetate (4R,5S)-1b (178 $\mathrm{mg}$, including solvent residue) was mixed with water $(150 \mathrm{~mL})$. Eggplant $S$. melongena $(70 \mathrm{~g})$ was cut into thin slices (c. $5 \mathrm{~mm}$ ) and added to the mixture, which was incubated in an open container at $25^{\circ} \mathrm{C} / 120 \mathrm{rpm}$ in a shaking water bath for $14 \mathrm{~h}$. The eggplant tissue was filtered off and rinsed with water (ca. $4 \times 60 \mathrm{~mL}$ ). The remaining aqueous solution was extracted with diethyl ether (ca. $5 \times 50 \mathrm{~mL}$ ), washed with water (ca. $2 \times 50 \mathrm{~mL}$ ) and brine (ca. $50 \mathrm{~mL}$ ), dried over $\mathrm{MgSO}_{4}$, and concentrated in vacuo to yield $53 \mathrm{mg}$ crude product. This product was subjected to MPLC and $42 \mathrm{mg}$ of $(4 R, 5 S)$-1a was isolated in $96 \%$ isomeric purity and 98\% chemical purity. Overall yield from 3-pentanone: $12 \% .{ }^{1} \mathrm{H}$ NMR $\delta$ : $3.82(\mathrm{~m}, 1 \mathrm{H}), 2.45-2.60(\mathrm{~m}, 3 \mathrm{H}), 1.52$ $(\mathrm{m}, 1 \mathrm{H}), 1.38(\mathrm{~m}, 1 \mathrm{H}), 1.13$ (d, 3H, $J=7.2 \mathrm{~Hz}), 1.06$ (t, 3H, $J=7.2 \mathrm{~Hz})$, 0.95 (t, 3H, $J=7.4 \mathrm{~Hz}) ;{ }^{13} \mathrm{C}$ NMR $\delta: 217.2,72.8,49.5,35.3,27.1,10.6$, 10.1, $7.8 \mathrm{ppm}$. For MS see syn-1a.

\subsection{Synthesis of $(4 S, 5 R)-5$-hydroxy-4-methyl-3-heptanone $((4 S, 5 R)-1 a)$}

Compound syn-1a [0.60 g, $4.2 \mathrm{mmol}$ (sum of isomers), 90\% syn] was mixed with vinyl acetate $(2.0 \mathrm{~g}, 23.2 \mathrm{mmol})$ and Amano PS-D lipase $(0.30 \mathrm{~g})$ was added. The mixture was incubated at $25^{\circ} \mathrm{C} /$ $120 \mathrm{rpm}$ in a shaking water bath. After 4 days the lipase was filtered off and rinsed with dichloromethane. The solvents were removed in vacuo, the product was isolated from the remaining starting material and enriched by repetitive MPLC (two times) yielding a fraction of $185 \mathrm{mg}(47 \%)(4 S, 5 R)-\mathbf{1 b}$ in $92 \%$ isomeric purity.

The acetate $(4 S, 5 R)-\mathbf{1 b}(185 \mathrm{mg}, 0.99 \mathrm{mmol})$ was mixed with water $(150 \mathrm{~mL})$. Eggplant ( $S$. melongena, $70 \mathrm{~g})$ was cut into thin slices (ca. $5 \mathrm{~mm}$ ) and added to the mixture, which was incubated in an open container at $25^{\circ} \mathrm{C} / 120 \mathrm{rpm}$ in a shaking water bath for $20 \mathrm{~h}$. The biological tissue was filtered off and rinsed with water (ca. $4 \times 50 \mathrm{~mL}$ ). The remaining aqueous solution was extracted with diethyl ether (ca. $3 \times 30 \mathrm{~mL}$ ), washed with water (ca. $2 \times 30 \mathrm{~mL}$ ) and brine (ca. $30 \mathrm{~mL}$ ), dried over $\mathrm{MgSO}_{4}$, and concentrated in vacuo to yield $61 \mathrm{mg}$ crude product. This product was subjected to MPLC and $42 \mathrm{mg}(4 S, 5 R)$-1a was isolated in $95 \%$ isomeric purity and $98 \%$ chemical purity. Overall yield from 3-pentanone: $12 \%$. For spectral data see $(4 R, 5 S)-\mathbf{1 a}$.

\subsection{Synthesis of $(4 R, 5 R)-5$-hydroxy-4-methyl-3-heptanone $((4 R, 5 R)-2 a)$}

Compound anti-2a [1.80 g, $12.5 \mathrm{mmol}$ (sum of enantiomers), $70 \%$ anti] was mixed with vinyl acetate $(7.2 \mathrm{~g}, 84 \mathrm{mmol})$ and Amano PS-D lipase ( $1.80 \mathrm{~g}$ ) was added. The mixture was incubated at $25^{\circ} \mathrm{C} /$ $120 \mathrm{rpm}$ in a shaking water bath. After two days the lipase was filtered off and rinsed with dichloromethane. The solvents were removed in vacuo and the product was isolated from the remaining starting material and enriched by repetitive MPLC (three times) yielding a fraction of $426 \mathrm{mg}(4 R, 5 R)-\mathbf{2 b}$ of $94 \%$ isomeric purity $\left(36 \%^{\dagger}\right)$.

The acetate $(4 R, 5 R)-\mathbf{2 b}(426 \mathrm{mg}, 2.3 \mathrm{mmol})$ was mixed with water $(300 \mathrm{~mL})$. Carrot $D$. carota $(90 \mathrm{~g})$ was cut into thin slices (ca. $3 \mathrm{~mm}$ ) and added to the mixture, which was incubated in an open container at $25^{\circ} \mathrm{C} / 120 \mathrm{rpm}$ in a shaking water bath for $64 \mathrm{~h}$. The biological tissue was filtered off and rinsed with water (ca. $4 \times 100 \mathrm{~mL}$ ). The remaining aqueous solution was extracted with diethyl ether (ca. $3 \times 50 \mathrm{~mL}$ ), washed with brine (ca. $50 \mathrm{~mL}$ ), dried over $\mathrm{MgSO}_{4}$, and concentrated in vacuo to yield $240 \mathrm{mg}$ crude product. This product was subjected to MPLC and a fraction of $85 \mathrm{mg}(4 R, 5 R)$-2a was isolated in 95\% isomeric purity and 98\% chemical purity. Overall yield from 3 -pentanone: $6 \% .{ }^{1} \mathrm{H}$ NMR $\delta$ : $3.62(\mathrm{~m}, 1 \mathrm{H}), 2.40-2.70(\mathrm{~m}, 3 \mathrm{H}), 1.58(\mathrm{~m}, 1 \mathrm{H}), 1.41(\mathrm{~m}, 1 \mathrm{H}), 1.13(\mathrm{~d}$ $3 \mathrm{H}, J=7.2 \mathrm{~Hz}), 1.05(\mathrm{t}, 3 \mathrm{H}, J=7.2 \mathrm{~Hz}), 0.98(\mathrm{t}, 3 \mathrm{H}, J=7.4 \mathrm{~Hz}) ;{ }^{13} \mathrm{C} \mathrm{NMR}$ $\delta$ : 217.1, 75.2, 50.8, 36.3, 27.8, 14.5, 10.1, 7.8 ppm. For MS see syn-1a.

\subsection{Synthesis of $(4 S, 5 S)$-5-hydroxy-4-methyl-3-heptanone $((4 S, 5 S)-2 a)$}

4-Methyl-3,5-heptanedione 5 [1.20 g, 7.6 mmol (calcd from 90\% purity)] was mixed with water $(1.8 \mathrm{~L})$. Oyster mushrooms $P$. ostreatus $(600 \mathrm{~g}$ ) were cut into thin slices (c. $5 \mathrm{~mm}$ ) and added to the mixture, which was incubated in six open $250 \mathrm{~mL}$ Pyrex bottles at $25^{\circ} \mathrm{C} / 120 \mathrm{rpm}$ in a shaking water bath for $72 \mathrm{~h}$. The biological material was filtered off and rinsed with water (ca. $4 \times 250 \mathrm{~mL}$ ). The remaining aqueous solution was extracted with diethyl ether (ca. $3 \times 200 \mathrm{~mL}$ ), washed with brine (ca. $200 \mathrm{~mL}$ ), dried over $\mathrm{MgSO}_{4}$, and concentrated in vacuo to yield $1.27 \mathrm{~g}$ crude product. This product was subjected to MPLC and a fraction of $287 \mathrm{mg}$ of $(4 S, 5 S)-2 a$ was isolated in $86 \%$ isomeric purity and $96 \%$ chemical purity.

The crude product $(4 S, 5 S)-2 a(287 \mathrm{mg}, 2.0 \mathrm{mmol})$ was mixed with vinyl acetate $(1.0 \mathrm{~g}, 12 \mathrm{mmol})$ and Amano PS-D lipase $(0.20 \mathrm{~g})$ was added. The mixture was incubated at $25^{\circ} \mathrm{C} / 120 \mathrm{rpm}$ in a shaking water bath. After 4 days the lipase was filtered off and rinsed with dichloromethane. The solvents were removed in vacuo and the enriched alcohol was isolated from the formed ester by MPLC yielding a fraction of $253 \mathrm{mg}(4 S, 5 S)-2 \mathbf{a}$ of $95 \%$ isomeric purity. Total yield from 3,5-heptanedione: $23 \%$.

\section{Acknowledgements}

This work was supported by the University of Kalmar, Sweden and the FRST-funded programme LINX0304 Ecosystem BioProtection, New Zealand.

\section{References and notes}

1. Schmuff, N. R.; Phillips, J. K.; Burkholder, W. E.; Fales, H. M.; Chen, C.-W.; Roller, P. P.; Ma, M. Tetrahedron Lett. 1984, 25, 1533.

2. Unelius, C. R.; Wee, S. L.; McNeill, M.; Daly, J.; Bunn, B. J.; Gibb, A. R.; Bohman, B.; Suckling, D. M. In preparation.

\footnotetext{
${ }^{\dagger}$ Yields calculated from the amount of $(4 R, 5 R)$-2a present in the racemic starting material, i.e., the yield obtained if $(4 S, 5 S)$-2a would have been retrieved from the reaction mixture.
} 
3. Some examples are (a) Mori, K.; Yoshimura, T.; Sugai, T. Liebigs Ann. Chem. 1988, 899; (b) Pilli, R. A.; Riatto, V. B. J. Braz. Chem. Soc. 1999, 10, 363; (c) Delas, C. Szymoniak, J.; Thery, N.; Moïse, C. Synth. Commun. 1998, 28, 2613; (d) Fujisawa, T.; Mobele, B. I.; Shimizu, M. Tetrahedron Lett. 1992, 33, 5567; (e) Fauve, A. Veschambre, H. Tetrahedron Lett. 1987, 28, 5037; (f) Kalaitzakis, D.; Rozzell, J. D.; Kambourakis, S.; Smonou, I. Eur. J. Org. Chem. 2006, 2309; (g) Mori, K.; Ebata, T. Tetrahedron 1986, 42, 4421 .

4. Evans, D. A.; Rieger, D. L.; Bilodeau, M. T.; Urpi, F. J. Am. Chem. Soc. 1991, 113, 1047.

5. Pontes, G. B.; Bohman, B.; Unelius, C. R.; Lorenzo, M. G.J. Chem. Ecol. 2008, 34, 450.

6. Baeckstrom, P.; Stridh, K.; Li, L.; Norin, T. Acta Chem. Scand. 1987, B41, 447.
7. Bohman, B.; Cavonius, L. R.; Unelius, C. R. Green Chemistry 2009. doi:10.1039/ b913936b

8. Swiss, K. A.; Choi, W.-B.; Liotta, D. C.; Abdel-Magid, A. F.; Maryanoff, C. A. J. Org. Chem. 1991, 56, 5978.

9. (a) Bolte, J.; Gourcy, J.-G.; Veschambre, H. Tetrahedron Lett. 1986, 27, 565; (b) Fauve, A.; Veschambre, H. J. Org. Chem. 1988, 53, 5215.

10. Koutek, B.; Korblova, E.; Kreckova, J.; Vrkoc, J. In Endocrinological Frontiers in Physiological Insect Ecology; Sehnal, F., Zabza, A., Denlinger, D. L., Eds.; Wroclaw Technical University: Wroclaw, 1988; pp 767-770.

11. Blight, M. M.; Pickett, J. A.; Smith, M. C.; Wadhams, L. J. Naturwissenschaften 1984, 71,480 . 